\title{
Magnetostratigraphy and paleomagnetic poles from Late Triassic- earliest Jurassic strata of the Newark basin: Discussion and reply Discussion
}

SPENCER G. LUCAS New Mexico Museum of Natural History, 1801 Mountain Road N.W., Albuquerque, New Mexico 87104 MAUREEN B. STEINER Department of Geology and Geophysics, University of Wyoming, Laramie, Wyoming 82071 PHILLIP HUBER Department of Geological Sciences, Ohio University, Athens, Ohio 45701

ADRIAN P. HUNT Department of Geology, University of Colorado at Denver, 1200 Larimer St., Denver, Colorado 80217
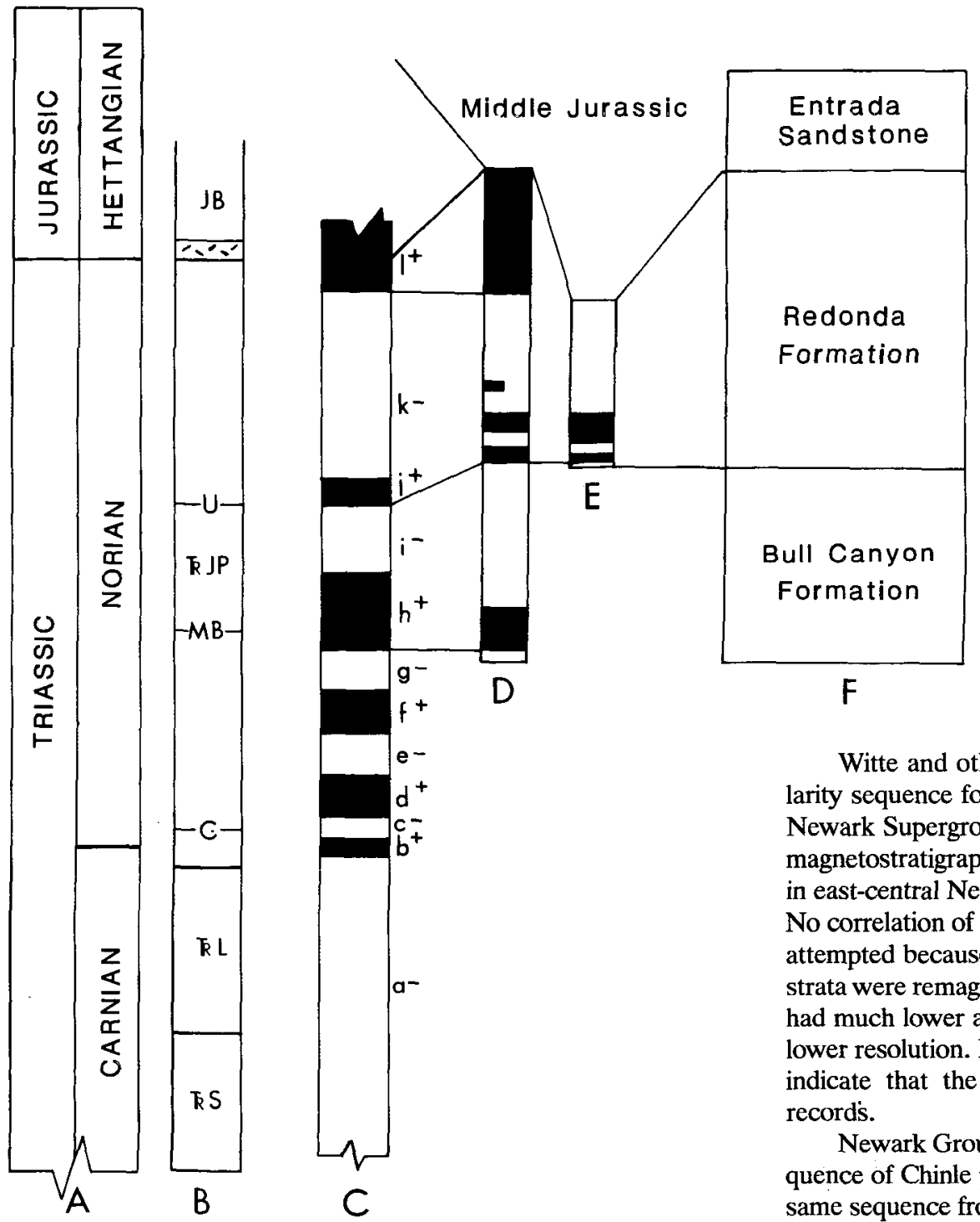

Figure 1. Correlation of Newark and Chinle magnetostratigraphies. Newark basin stratigraphic units (B) and polarity sequence (C) from Witte and others (1991). Chinle polarity sequence at Luciano Mesa (D) and Mesa Redonda (E) from Reeve and Helsley (1972), and stratigraphic terms (F) from Lucas and Hunt (1989). Placement of Carnian-Norian boundary at the base of the Passaic Formation (FJP) corrects a drafting error in Witte and others (1991).

The article discussed appeared in the Bulletin, v. 103, p. 1648-1662.

Geological Society of America Bulletin, v. 105, p. 1260-1262, 1 fig., September 1993. 
Chinle Group sequence has been as intensively studied as the Newark, the same pattern in pole positions is observed. This similarity argues not only against remagnetization, but also for similar ages of magnetization.

The magnetostratigraphic data from the two rock units (Fig. 1) also are similar. Reeve and Helsley (1972) measured magnetostratigraphic sections in only the uppermost part of the Chinle Group. In east-central New Mexico, at Luciano Mesa, Reeve and Helsley (1972, spelled Lucianna in their text) sampled the upper $60 \mathrm{~m}$ of the $95-\mathrm{m}$ thick Bull Canyon Formation and the entire $85 \mathrm{~m}$ of the Redonda Formation. They sampled the Redonda Formation again $40 \mathrm{~km}$ to the east (Mesa Redonda) and obtained the same magnetostratigraphy. The 145-m-thick section that Reeve and Helsley sampled overlies 400-500 m of additional Upper Triassic strata (Lucas and Hunt, 1989).

The early-middle Norian age of the Bull Canyon Formation in east-central New Mexico is well established by tetrapod correlations based principally on phytosaurs and aetosaurs (Lucas and Hunt, 1989), corroborated by Norian palynomorphs in correlative units on the Colorado Plateau (Litwin and others, 1991).

The Redonda Formation also is of Norian age, and fossil vertebrates and sequence stratigraphic correlations indicate it is late Norian or Rhaetian, younger than the Columbianus Zone of ammonoid biochronology and therefore post-Alaunian (Lucas, 1991). The Redonda Formation is a correlative of the upper part of the Passaic Formation in the Newark basin, no older than the Ukrainian Village Member (Fig. 1). Therefore, the uppermost normal interval of the Redonda correlates to the $\mathrm{I}^{+}$interval in the Newark basin, and the lowest normal interval in the Reeve and Helsley section is equivalent to, or perhaps younger than, the $\mathrm{j}^{+}$normal interval of the Newark basin (Fig. 1).

This correlation appears to indicate that several short intervals of normal polarity are recorded in the Redonda Formation but not in the upper Passaic Formation. Close examination of Reeve and Helsley's (1972) data, however, suggests that several of the short intervals they interpreted as normal polarity may be incorrect. The upper of the two closely spaced, short, normal-polarity intervals at Luciano Mesa (Reeve and Helsley, 1972, fig. 3) is not convincingly of normal polarity and may be the product of unremoved secondary magnetization of recent origin. Also, more samples and better demagnetization are needed to verify the lower of those two short normal-polarity intervals. Likewise, the short normal-polarity interval near the top of Reeve and Helsley's Mesa Redonda section appears to be an overprint of present-field magnetization on reversed polarity, similar to overprints seen $\sim 10 \mathrm{~m}$ lower.

With or without these caveats, however, the Newark Group magnetostratigraphy correlates well with the Chinle Group magnetostratigraphy (Fig. 1). This correlation indicates that the Chinle Group preserves at least one more pair of normal and reversed-polarity intervals than does the coeval Newark sequence. One explanation of this apparent lack of temporal resolution in the Newark basin may be the very coarse sampling density and long, unsampled stratigraphic intervals (as much as 500-1,000 m thick) enforced on Witte and others (1991) by the lack of outcrop. Nevertheless, the Newark Group correlates well with the Chinle Group magnetostratigraphy, and the Chinle sequence provides better temporal resolution than does the much thicker Newark section.

\section{REFERENCES CITED}

Litwin, R. J., Traverse, A., and Ash, S. R., 1991, Preliminary palynological zonation of the Chinle Formation, southwestern U.S.A., and its correlation to the Newark Supergroup (eastern U.S.A.): Review of Palaeobotany and Palynology, v. 68, p. 269-287.

Lucas, S. G., 1991, Sequence stratigraphic correlation of nonmarine and marine Late Triassic biochronologies, western United States: Albertiana, v. 9, p. 11-18.

Lucas, S. G., and Hunt, A. P., 1989, Revised Triassic stratigraphy in the Tucumcari basin, east-central New Mexico, in Lucas, S. G., and Hunt, A. P., eds., Dawn of the age of dinosaurs in the American Southwest: Albuquerque, New Mexico, New Mexico Museum of Natural History, p. 150-170. Reeve, S. C., and Helsley, C. E., 1972, Magnetic reversal sequence in the upper portion of the Chinle Formation, Montoya, New Mexico: Geological Society of America Bulletin, v. 83, p. 3795-3811. Witte, W. K. Kent, D. V., and Olsen, P. E., 1991, Magnetostratigraphy and paleomagnetic poles from the Late Triassic-earliest Jurassic strata of the Newark basin: Geological Society of America Bulletin, v. 103, p. 1648-1662.

MANUSCRIPT RECETVED BY THE SOCIETY NOVEMBER 24, 1992 MANUSCRIPT ACCEPTED FEBRUARY 25, 1993

\title{
Reply
}

\author{
WILLIAM K. WITTE \\ DENNIS V. KENT $\}$ Lamont-Doherty Earth Obsenvatory of Columbia University, Palisades, New York 10964 \\ PAUL E. OLSEN
}

The Discussion of Lucas and others underscores the potential usefulness of magnetostratigraphy for correlation between red beds of the broadly coeval Chinle Group of the western interior and the Newark Supergroup of eastern North America. Detailed magnetostratigraphic correlation between the Newark and the Chinle is very likely to change significantly, however, with the addition of new data from both of these units, and hence such an attempt as proposed in the Discussion may be premature.

In view of positive reversal tests reported for the Owl Rock Member (Bazard and Butler, 1991) and our restudy of the Church Rock Member (Kent and Witte, 1993), we have also concluded that complete remagnetization of the Chinle is increasingly unlikely. As described in Kent and Witte (1993), the similarities and differences between the sequence of Newark poles and Chinle poles from on and off the Colorado Plateau are instead better explained by post-Triassic tectonic rotations of the Colorado Plateau with respect to cratonic North America. Unremoved overprints, nevertheless, confound the interpretation of the Chinle magnetostratigraphy reported by Reeve and Helsley (1972).

Although the Discussion suggests that the magnetostratigraphic records from the Newark and Chinle sections are similar, this characterization is misleading in several respects. The Newark samples were subjected to complete progressive thermal demagnetization in 15 to 20 steps to at least $680^{\circ} \mathrm{C}$, and characteristic directions were estimated from principal components analysis of the magnetization remaining above $640^{\circ} \mathrm{C}$. Of the 64 sedimentary sites in the Newark 


\section{DISCUSSION AND REPLY}

summarized in Witte and others (1991), 92\% yielded what were judged to be reliable data for magnetostratigraphic interpretation. Progressive thermal demagnetization to $630^{\circ} \mathrm{C}$ was performed on 24 pilot samples in the Reeve and Helsley (1972) study, but the Chinle Luciano Mesa (following spelling in Discussion) and Redonda Mesa magnetostratigraphies cited in the Discussion are based primarily on sample magnetizations after demagnetization to only $550 \pm 30^{\circ} \mathrm{C}$. In general, progressive thermal demagnetization above $550^{\circ} \mathrm{C}$, up to the maximum unblocking temperature of hematite at about $680^{\circ} \mathrm{C}$, has been found to be essential to isolate characteristic magnetizations in the Chinle red beds (Bazard and Butler, 1991; Molina-Garza and others, 1991; Kent and Witte, 1993). Reeve and Helsley (1972) realized that the stable Triassic magnetizations in the Chinle are clearly revealed only in the very high unblocking temperature range, and they noted that a large number of their samples retained directions associated with the present field to demagnetization temperatures of $550^{\circ} \mathrm{C}$ and even higher. In their Discussion, Lucas and others accordingly suggest that several normal polarity intervals interpreted by Reeve and Helsley (1972) at Luciano Mesa and Redonda Mesa may be artifacts of the incomplete removal of secondary magnetization components. Thus, although complete remagnetization of the Chinle is unlikely, we also agree that secondary magnetizations confuse the available polarity zonation of the Luciano Mesa and Redonda Mesa sections of the Chinle.

The resulting ambiguity in the correlation of the Chinle magnetostratigraphy to the Newark record is exacerbated by gaps in the Chinle's depositional history, as well as gaps in the magnetostratigraphic sampling of both the Chinle and Newark sections. That the Chinle and the Newark represent "similar time records" is generally accepted in the sense that both sequences are assigned Carnian and Norian biostratigraphic ages (Comet and Olsen, 1985; Lucas, 1991a). Deposition in the Newark basin began sometime in the Carnian with the palynologically defined Carnian/Norian boundary falling between the top of the Lockatong Formation and the base of the Perkasie Member of the Passaic Formation, as originally described by Cornet (1977) and shown in Figure 1 of the Discussion. Newark deposition apparently continued without any significant hiatus through the Norian and into the earliest Jurassic and preserves an apparently complete record of climatic fluctuations interpreted as Milankovitch cycles (Olsen and others, 1989). The Chinle stratigraphic record is, on the other hand, interrupted by several important regional unconformities of imprecisely known duration (for example, the $\operatorname{Tr}-5$ and $\mathrm{J}-0$ unconformities at the tops of the Bull Canyon and Redonda formations, respectively; Lucas, 1991a, 1991b). For example, the upper part of the Redonda Formation is apparently normal polarity at $\mathrm{Lu}$ ciano Mesa (Fig. 1D of Discussion) but is reversed polarity at Redonda Mesa (Fig. 1E of Discussion), suggesting that the unconformity at the top of the Redonda Formation may even be diachronous at the two locales. Furthermore, the much greater thickness of the Newark section $(-6,000 \mathrm{~m})$ relative to the broadly coeval Chinle sections $(\sim 145 \mathrm{~m}$ in Fig. 1 of the Discussion, and several hundred meters in the sections described by Lucas [1991a]) suggests that the Newark has the potential for a considerably higher overall temporal resolution than the Chinle.

The Discussion reiterates our conclusion (Witte and others, 1991) that several large sampling gaps (as much as $1,000 \mathrm{~m}$ and corresponding to several million years) in our outcrop study of the Newark make it likely that we have missed some polarity intervals, especially within the Newark $\mathrm{a}^{-}$and $\mathrm{k}^{-}$magnetozones. It is also evident that some magnetozones may have been missed in the Chinle sections studied by Reeve and Helsley (1972), especially in the lower Luciano Mesa section, where several sampling gaps are at least as wide $(\sim 10 \mathrm{~m})$ as some of the thinner magnetozones $(\sim 1$ to $5 \mathrm{~m})$ they interpret in the Chinle. Through recent continuous coring in the Newark basin (Olsen and Kent, 1990; Kent and Olsen, 1992), we are in the process of obtaining a complete high-resolution record of Late Triassic geomagnetic polarity history (Kent and others, 1992). It would be extremely useful if there were a complementary modern restudy of the Luciano Mesa and Redonda Mesa sections, consisting of detailed demagnetization analysis of a sufficiently high density of samples, to delineate with high reliability the fine structure of Chinle magnetostratigraphy.

With a complete Newark magnetic-polarity reference section and the results from magnetostratigraphic studies of the Chinle all based upon well-isolated characteristic magnetization directions, it should then be possible to establish very detailed correlations between the Newark and the various Chinle sections (Reeve and Helsley, 1972; Bazard and Butler, 1991; Molina-Garza and others, 1991). This should allow the evaluation of the temporal extent of the regional unconformities in the Chinle described by Lucas (1991b) and provide an exciting opportunity to calibrate the exceptionally rich vertebrate biostratigraphy of the Chinle with the Newark's continuous time stratigraphic section and cyclostratigraphic numerical chronology (Olsen and others, 1992).

\section{ACKNOWLEDGMENTS}

This research was supported by National Science Foundation Earth Sciences Grant EAR89-16726. This is Lamont-Doherty Earth Observatory contribution no. 5052.

\section{REFERENCES CITED}

Bazard, D. R., and Butler, R. F., 1991, Paleomagnetism of the Chinle and Kayenta Formations, New Mexico and Arizona: Journal of Geophysical Research, v. 96, p. 9847-9871

Cornet, B., 1977, The palynostratigraphy and age of the Newark Supergroup [Ph.D. thesis]: University Park, Pennsylvania, Pennsylvania State University, $506 \mathrm{p}$.

Comet, B., and Olsen, P. E., 1985, A summary of the biostratierat Eastern North America with comments on early Mesozoic provinciality, in III Congreso Latinoamericano de Paleontología, Mexico, Simposio Sobre Flores del Triasico Tardío, Su. Fitogeografía y Paleoecologia, Memoria, p. 67-81.

Kent, D. V., and Olsen, P. E., 1992, Newark continental rift basin coring project: International Geological Congress, 29th, Kyoto, Japan, Abstracts, p. 30.

Kent, D. V., and Witte, W. K., 1993, Slow apparent polar wander for North America in the Late Triassic and large Colorado Plateau rotation: Tectonics, v. 12, p. 291-300.

Kent, D. V., Witte, W. K., and Olsen, P. E., 1992, Late Triassic geomagnetic polarity reference sequence from the Newark continental rift basin: International Geological Congress, 29th, Kyoto, Japan, Abstracts, p. 141 .

Lucas, S. G., 1991a, Correlation of Triassic strata of the Colorado Plateau and southern High Plains, New Mexico: New Mexico Bureau of Mines and Mineral Resources Bulletin, v. 137, p. 47-56. Lucas, S. G., 1991b, Sequence stratigraphic correlation of nonmarine and marine Late Triassic biochronologies, westem United States: Albertiana, v. 9, p. 11-18.

Molina-Garza, R. S., Geissman, J. W., Van der Voo, R., Lucas, S. G., and Hayden, S. N., 1991, Paleomagnetism of the Moenkopi and Chinle Formations in central New Mexico: Implications for the North American Apparent Polar Wander Path and Triassic magnetostratigraphy: Journal of Geophysical Research, v. 96 , p. 14,239-14,262.

Olsen, P. E., and Kent, D. V., 1990, Continental coring of the Newark rift: Eos (American Geophysical Union Transactions),, 17, p. 385-394

Olsen, P. E., Schlische, R. W., and Gore, P.J.W., 1989, Tectonic, depositional, and paleocological history of the early Mesozoic rift basins, eastern North America: American Geophysical Union Field Trip Guide Book T351, 174 .

Olsen, P. E., Kent, D. V., Reynolds, D Comet, B and Witte, W. K, 1992 Evolutive spectral analysis of 24 million years of early Mesozoic orbital forcing from the lacustrine Newark rift basin cores: of 24 million years of early Mesozoic orbital forcing from the lacustrine N

Reeve, S. C., and Helsley, C. E., 1972, Magnetic reversal sequence in the upper portion of the Chinle Formation, Montoya, New Mexico: Geological Society of America Bulletin, v, 83, p. $3795-3812$.

Witte, W. K., Kent, D. V., and Olsen, P. E., 1991, Magnetostratigraphy and paleomagnetic poles from Late Triassic-earliest Jurassic strata of the Newark Basin: Geological Society of America Bulletin, v. 103, p. 1648-1662.

MANUSCRIPT RECEIVED BY THE SOCIETY FEBRUARY 25, 1993

MANUSCRIPT ACCEPTED FEBRUARY 25, 1993 